\title{
ТРЕТІЙ УНІВЕРСАЛ УКРАЇНСЬКОЇ ЦЕНТРАЛЬНОЇ РАДИ І ХАРКІВСЬКЕ МІСЬКЕ СУСПІЛЬСТВО
}

\author{
Д. М. Чорний
}

\begin{abstract}
Чорний Д. М. Третій Універсал Української Центральної Ради і харківське міське суспільство. У статті розкривається реакція харківського суспільства на Третій Універсал Української Центральної Ради. Розглядається обговорення Універсалу в Харківській міській думі та проаналізовано позиції головних фракцій. Визначено особливості реакції на нього: підтримка, рішуче неприйняття та нейтральне ставлення, мотиви, якими керувалися політичні фракції. Стверджується, що реакція гласних Харківської Думи адекватно відображала ставлення різних верств міського населення до політики Української Центральної Ради.
\end{abstract}

Ключові слова: Третій Універсал; Українські Установчі збори; гласний; фракція.

Черный Д. Н. Третий Универсал Украинской Центральной Рады и харьковское городское общество. В статье раскрывается реакция харьковского общества на Третий Универсал Украинской Центральной Рады. Рассматривается обсуждение Универсала в Харьковской Городской Думе и проанализированы позиции главных фракций. Определены особенности реакции на него: поддержка, решительное непринятие и нейтральное отношение, мотивы, которыми руководствовались политические фракции. Утверждается, что реакция гласных Харьковской Думы адекватно отображала отношение разных слоев городского населения к политике Украинской Центральной Рады.

Ключевые слова: Третий Универсал; Украинское Учредительное собрание; гласный; фракция.

Chornyi D. M. The Third Universal of Ukrainian Central Rada and Kharkiv City Society. The article reveals the reaction of the Kharkiv society on the Third Universal of the Ukrainian Central Rada. The discussion of the Universal in the Kharkiv City Duma is considered and the positions of the main factions are analyzed. The types of reaction of the different political forces : support, decisive rejection, neutral attitude, and motives of actions by political factions are determined. It is alleged that the reaction of the councilors of the Kharkiv Duma adequately reflected the attitude of different groups of the city-dwellers towards the policy of the Ukrainian Central Rada.

Keywords: The Third Universal; the Ukrainian Constituent Assembly; councilor; faction.

В 1917 р. життя мешканців українських губерній стрімко змінювалося через триваючу світову війну, погіршення соціально-економічної ситуації, загострення боротьби між різними політичними партіями. Активними гравцями на політичній сцені стали Українська Центральна Рада (УЦР) та більшовики, протистояння між якими поступово наближалося до межі відкритої боротьби. Градус суспільної напруги зростав щомісяця і сягнув апогею в листопаді-грудні. Третій Універсал УЦР, покликаний дати вихід із глухого кута, в який загнали країну дії Тимчасового уряду та більшовицький переворот в Петрограді, спонукав місцеві суспільство та політичну еліту шукати відповідь на складні питання вибору вектору розвитку.

Дослідження життя Харкова другої половини 1917 р. залишається однією 3 «білих плям» історіографії, попри, здавалось би, наявність значного масиву наукових публікацій. У більшості монографій, наукових статтях ситуація розглядається крізь призму протистояння між силами, лояльними до Тимчасового уряду, Української Центральної Ради та більшовиків. Зокрема, в публікаціях радянських істориків в центрі уваги перебувала боротьба більшовиків за встановлення контролю над Харківською радою робітничих і солдатських депутатів, конструювання «об' єктивних передумов» перемоги більшовиків, з'ясування дати встановлення їхньої влади у місті ${ }^{1}$. Сучасна українська історіографія головну увагу приділяє українському національному руху, боротьбі Центральної Ради за регіон, обставинам виникнення та перебігу першої більшовицько-української війни ${ }^{2}$. Події в місті висвітлюються переважно крізь призму передвиборчої кампанії до міської Думи ${ }^{3}$ І Історія Харкова кінця 1917 р. як об’єкта протистояння «зовнішніх» сил відтворена на сторінках узагальнюючого фундаментального дослідження про місто у XX столітті, що вийшло у 2004 p. ${ }^{4}$. 
Зважаючи на сказане, ми ставимо за мету дослідити реакцію харківського міського суспільства на один із визначальних документів доби - Третій універсал УЦР. В центрі уваги будуть обговорення та ухвалення відповідного рішення Харківською Міською Думою. В Журналі їі засідань збереглися документи, що надають можливість реконструювати ставлення харківського суспільства до Третього Універсалу, проголошення УНР та входження регіону до ії складу.

Наприкінці 1917 р. у Харкові проживали понад 288 тис. осіб, або на 48,1 тис більше, ніж напередодні Першої світової війни. Значну частину мешканців становили біженці, евакуйовані, робітники промислових підприємств, що працювали на потреби фронту, військові. Завдяки демократичним перетворенням після Лютневої революції в Росії всі городяни отримали нові можливості для прояву громадської активності. Індикатором політичних уподобань жителів стали результати голосування на виборах до Міської Думи у липні 1917 р. та загальноросійських Установчих Зборів в листопаді 1917 р., які вперше відбувалися на засадах загального, рівного, прямого виборчого права.

На 116 місць до Міської Думи претендували кандидати від 13 політичних сил (списків), які можна поділити на три групи: загальноросійські Партія Народної свободи (ПНС, кадети), дві РСДРП в особі меншовиків та більшовиків, соціалісти-революціонери, Трудова народно-соціалістична партія (ТНСП); національні політичні партії і угруповання - дві українські, а саме Харківська організація УСДРП, Український демократичний блок, три єврейські, об'єднання польських громадських організацій; Союзи місцевих квартиронаймачів та поштово-телеграфних службовців.

Попри те, що у голосуванні взяли участь трохи більше половини - 82,2 тис. виборців, внесених до виборчих списків, цей показник означав колосальне зрушення в політичній активності міського населення, адже серед тих, що зареєструвалися, прийшли голосувати $91 \% 5$, в той час як на всіх попередніх виборах до місцевого самоврядування явка становила близько третини від тих, хто мав право голосу ${ }^{6}$.

Переконливу перемогу в Харкові здобули соціалісти-революціонери. За їх список «Земля и Воля» проголосували 46,4\% городян. Друге місце вибороли кадети, отримавши $13,5 \%$ голосів, третє посіли меншовики із 11,6\%. За ними йшли РСДРП(б) - 9,3\%, ТНСП - 6,9\%, Об'єднаний єврейський список - 4,5\%. Інші політичні сили здобули $0,5-1,8 \%$ голосів. Таким чином, перше демократично обране міське самоврядування Харкова склали 54 соціалісти-революціонери, 16 кадетів, 13 меншовиків, 11 більшовиків, 8 представників ТНСП, 5 - Об'єднаного єврейського списку та по 1-2 гласних від інших сил ${ }^{7}$.

Восени 1917 р. значна зміна політичної та соціально-економічної ситуації в країні обумовила зміни у політичних симпатіях городян, посилення поляризації та розпорошення політичних сил. Індикатором цих змін $є$ вибори до загальноросійських Установчих зборів. У Харківській губернії було висунуто 16 списків. Голосування виявило незначне зростання активності виборців порівняно із серпнем 1917 р.: 98,8 тис. Харків'ян прийшли на виборчі дільниці. Результати виборів засвідчили суттєву зміну симпатій та антипатій виборців губернського центру порівняно із виборами до Міської Думи. У Харкові більшість голосів здобули більшовики - 27,8\%. Незначно відстали від них кадети $-25,2 \%$, в той час як есери посіли лише третю сходинку, набравши $12,7 \%$ голосів ${ }^{8}$. Водночас вибори засвідчили суттєву відмінність у політичних симпатіях мешканців губернського центру і решти губернії, адже в цілому по округу абсолютну перемогу здобули російські та українські соціалісти-революціонери, за яких проголосувало 72,8\% виборців. Друге місце посіли більшовики - $10,5 \%$, третє - кадети $-5,3 \%$.

Зміну політичних пріоритетів харків'ян порівняно із виборами липня 1917 р. можна пояснити тим, що, по-перше, партія соціалістів-революціонерів, якій суспільна свідомість городян «приписувала» статус правлячої та орієнтованої переважно на захист інтересів селян, в умовах наростаючої нестабільності втрачала авторитет виборців. Крім того, вона розкололася на кілька фракцій, що позначилося на ситуації всередині Міської Думи. Натомість успіх партії кадетів свідчив про зростаючий «запит» мешканців міста на стабільність, на ліберальні цінності, поширені у місті в передвоєнний період.

По-друге, 25 жовтня 1917 р. в Петрограді більшовики шляхом збройного повстання усунули від влади законний Тимчасовий уряд Російської республіки. Створена більшовиками Рада народних комісарів (РНК) розпочала реалізацію планів щодо встановлення 
контролю над всією країною, укладання миру із Німеччиною та її союзниками, проведення земельної реформи. Ці події мали вирішальне значення для розвитку ситуації в Харкові. Насильницькі дії представників однієї партії призвели до загострення політичної кризи, дезорієнтували багатьох політиків та рядових громадян.

По-третє, виникла реальна загроза неконтрольованої децентралізації країни, адже, крім УЦР, формувалися та діяли нові політичні центри тяжіння у Фінляндії, Прибалтиці, на Дону, Північному Кавказі, Закавказзі, Волзі, Уралі, в Сибіру ${ }^{9}$, де не визнавали повноважень нелегітимної РНК. Намагаючись уникнути хаосу, УЦР 7 листопада 1917 р. видала Третій Універсал, яким проголосила Україну Народною Республікою (УНР), яка не відділяючись від Російської республіки, зберігає ії єдність. Згідно Універсалу, до території УНР мають належати землі, заселені в більшості українцями, серед них - Харківщина, а на тих територіях суміжних Курської та Воронезької губерній, де більшість населення українська, приналежність до УНР «має бути встановлене по згоді організованої волі народів». Також УЦР наполягала, що мир треба встановлювати якнайшвидше, впливаючи через центральний уряд на союзників і противників щодо негайного початку мирних переговорів. Універсалом передбачалось «вжити реальних заходів до закріплення і поширення прав місцевого самоврядування», яке на той час представляли земства та міські думи. Для закріплення демократичним шляхом всіх перетворень УЦР наголошувала на необхідності скликання Українських та Всеросійських Установчих зборів ${ }^{10}$.

Таким чином виникла ситуація, коли регіони втрутилися у розв'язання питань загальнодержавного рівня. Обставини владно вимагали визначеності від населення та політичних лідерів на місцях. Рішення місцевих органів влади, спрямовані як на загострення конфліктів, так і на пошук компромісних рішень, ставали вирішальними для долі України і Росії.

Під впливом цих чинників розгортались процеси, з одного боку, посилення політичної поляризації суспільства та активності маргінальних угруповань, а з іншого боку - апатії, небажання значної частини мешканців брати участь у виснажливій політичній боротьбі. Як свідчать дані про участь у виборах, документи особистого походження, значна частина харків'ян відсторонено ставилась до політичних катаклізмів. Набагато більше городян турбували ускладнення із постачанням продуктів харчування, інших товарів, ніж дії та зміни центральної влади. Спричиняли таку лінію поведінки значної кількості рядових мешканців певна втома від політики та політиків, неготовність активно захищати свої політичні інтереси.

Більшість харківських політиків місцевого походження надавали перевагу пошуку виходу із гострого політичного кута на шляху компромісів і коаліцій. Спроби більшовиків одразу по отриманні повідомлень про переворот в Петрограді захопити в свої руки владу не увінчалися успіхом. 26 жовтня 1917 р. в Харкові було створено Воєнно-революційний комітет (ВРК) з 56 осіб на принципах представництва від усіх політичних сил: по 5 осіб представляли Раду робітничих і солдатських депутатів, Раду селянських депутатів та Міську Думу, троє - обласний комітет Рад робітничих і солдатських депутатів, по одномудва члени делегували заводські комітети, профспілки, залізниці, політичні партії, 30 представляли українські організації - Раду Слобідської України та Військову раду. Таким чином ВРК, в якому домінували проукраїнськи налаштовані діячі, декларував своє завдання так: «Не диктатура одного загону демократії над рештою демократії і всією країною, а коаліція спілок всієї демократії в ім'я порятунку країни, революції, в ім'я придушення контрреволюції» ${ }^{11}$, виразно маючи намір уникнути братовбивчої громадянської війни в регіоні.

ВРК, здыйснюючи контроль над більшістю військових формувань, розташованих у місті, спромігся нейтралізувати 27-30 жовтня наступ на Харків військ, прихильних до поваленого Тимчасового уряду, зокрема Чугуївської школи юнкерів, який організував «Губернський комітет порятунку батьківщини та революції», складений з кадетів, правих есерів, меншовиків-оборонців тощо.

Але більшовики, що перебували в меншості у складі ВРК, намагалися захопити всю повноту влади в свої руки. Не спромігшись одразу добитися повної підтримки дій своїх лідерів у Петрограді, харківські більшовики пішли шляхом поступового проникнення у місцеві ради різного рівня та ревізії їх попередніх рішень. Вони організували 7-8 листопада 1917 р. перевибори Ради робітничих та солдатських депутатів на частині заводів, внаслідок чого спромоглися здобути 47,5\% місць у Раді. 10 листопада Харківська рада 
робітничих і солдатських депутатів ухвалила резолюцію про передачу влади Радам, у якій містилася компромісна формула підтримки як РНК в Петрограді, так і УНР, скликання Українських Установчих зборів ${ }^{12}$.

Між 19-24 листопада більшовики добилися переобрання виконкому Харківської Ради робітничих та солдатських депутатів, отримання в ній більшості місць і обрання головою виконкому більшовика Артема (Ф. А. Сергєєва). Після цього виконком Ради ухвалив резолюцію, спрямовану проти УЦР та висловився за підтримку РНК. Паралельно більшовики інтенсивно формували загони Червоної гвардії та намагалися поставити питання про розпуск ВРК. Але наступ військ генерала Л. Корнілова, які називали контрреволюційними, примусив всіх місцевих політиків знов діяти спільно. Між 26 листопада - 6 грудня організовані ВРК частини у боях під Бєлгородом розбили корніловські частини.

Паралельно із розгортанням цих подій місто ставало осередком концентрації більшовицьких військ, головною причиною якої став геополітичний фактор: конкуренція між РНК та УЦР за контроль над Україною. Так, 20 листопада 1917 р. у Брест-Литовську почалися сепаратні переговори між делегацією РНК та Німеччиною і ії союзниками. 21 листопада УЦР вирішила направити своїх представників у Брест-Литовськ. Для рядового обивателя, далекого від тонкощів політичної гри, складалося враження, що УЦР розпочала здійснювати самостійну зовнішню політику.

За таких умов в другій половині 1917 р. єдиним законним та стабільно працюючим органом влади у м. Харкові залишалася Міська Дума. Вона намагалась зберегти системний підхід до забезпечення життєдіяльності всіх сфер міського життя. Але все частіше Дума мала займатися суто політичними справами. Оскільки представлені в ній сили віддзеркалювали політичний спектр настроїв харків'ян, заяви представників фракцій важливі для 3'ясування політичних пріоритетів жителів.

Харківська Міська Дума на засіданнях 29 листопада та 2 грудня 1917 р. обговорювала питання «Про ставлення до 3-го Універсалу Центральної Української Ради про проголошення Української Республіки, із включенням до неї Харківської губернії». Позиції різних політичних груп були зафіксовані в усних заявах, письмових проектах резолюцій та кінцевій резолюції, ухваленій Думою ${ }^{13}$.

Як свідчить Журнал засідань Харківської Міської Думи, в обговоренні зазначеного питання взяли участь представники 14 фракцій та груп. Але 45\% гласних не брали участі в обговоренні питання. Отже, поведінка міської еліти була типологічно подібною із ситуацією кінця буремного 1905 р., коли у засіданні Міської Думи брали участь лише 25\% гласних ${ }^{14}$.

Розгляд питання розпочався 29 листопада із виступу С. П. Тимошенка від фракції українських соціал-демократів. Він запропонував, щоби Дума визнала Центральну Раду та виконавчий орган Генеральний Секретаріат вищою владою на території Української республіки, всебічно сприяла успішному проведенню виборів до Українських Установчих зборів. Українські соціал-демократи також вітали рішучі кроки УЦР та Генерального Секретаріату щодо боротьби із анархією та економічним розвалом, які ведуть і Україну, і Росію до загибелі, здійснені УЦР кроки до укладання перемир'я і миру у згоді із союзниками та їх намагання організації «загальносоціалістичного загальноросійського уряду Федеративної Російської Республіки». У Журналі Думи зазначено, що слідом виступили представники українського демократичного блоку Г. М. Хоткевич та українських соціалістів-революціонерів А. І. Соколовський, які підтримали С. П. Тимошенка ${ }^{15}$.

Далі взяв слово представник російських соціалістів-революціонерів В. А. Ага-Беков. Сутність позиції донедавна найбільшої фракції, представленої в Думі, полягала в тому, щоб Харків приєднався до, за його формулюванням, «Української Демократичної республіки» як складової частини Всеросійської Федеративної республіки на підставі ухвалених УЦР положень про санкціонування Української республіки Загальноросійськими Установчими зборами, рішенню яких має передувати воля всієї України, висловлена на Українських Установчих зборах. Останні мають бути скликані за 4-членною формулою без різниці національності, віросповідання, статі, за пропорційною системою за умови гарантії прав національних меншин. Есери пропонували до часу створення Українськими Установчими зборами правильно сконструйованої народної влади визнати крайовим органом влади Генеральний Секретаріат УЦР, що спирається у справах управління Україною 
на органи революційної української демократії і демократії національних меншин, а також органи місцевих самоврядувань ${ }^{16}$. Позицію есерів підтримав представник єврейської соціалістичної партії М. Б. Лівшиц.

Інші аргументи щодо мотивування позитивного рішення Думи запропонував промовець від єврейської соціал-демократичної партії «Поалей-Ціон» 3. М. Хейфец. У заяві, виголошеній ним від імені фракції, наголошувалося, що за кожною національністю демократія має визнати право на повне самовизначення, отже тому кожна народність і область на своїх Установчих зборах має самостійно вирішити питання про форми і межі свого самоуправління. Загальноросійські Установчі збори, на думку фракції, мають дати лише свою формальну санкцію цим рішенням, якщо рішення окремих національних і територіальних Установчих Зборів не виявляться такими, що виключають одне одного, а питання, спірні між різними націями, мають бути вирішені угодою народів Росії, зокрема - про спірні території - голосуванням населення відповідних територій. До проведення відповідного плебісциту єдиним тимчасовим критерієм при визначенні кордонів окремих автономних областей може бути етнографічний принцип. Вважаючи, що Третій Універсал відповідає цим принципам, єврейська соціал-демократична партія «Поалей-Ціон» висловилася безумовно за участь населення Харківської губернії у виборах до Українських Установчих зборів. В разі вимоги про проведення плебісциту з боку ради або органів місцевих демократичних самоврядувань, він має бути оперативно проведений. До тих пір, поки плебісцит не проведено, «Харківська губернія як українська за складом населення, має увійти до складу Української республіки, центральним органом якої сьогодні є Центральна Рада», - підсумував представник «Поалей-Ціон» ${ }^{17}$.

Від народних соціалістів промовляв відомий у Харкові політик Н. Н. Познанський. Він наголосив, що його партія завжди стояла і виступає за найширше національне самовизначення, вимагає найширшої федерації і тому вважає, що і Україна за умов відповідного волевиявлення населення має увійти до складу загальноросійської федеративної республіки як окремий член цієї федерації. Проте із загальнодержавної точки зору, на думку фракції, як практичне здійснення автономії тієї чи іншої області, так і визначення кордонів цієї області, має бути здійснено згідно рішення загальноросійських Установчих зборів та шляхом опитування місцевого населення. Фракція ТНСП заявила, що не може визнати дії УЦР ані правомірними, ані такими, що відповідають інтересам як російського, так і українського народів, їх не можна вважати обов'язковими для населення м. Харкова. Головними аргументами ТНСП проти підтримки Третього Універсалу були відсутність рішення загальноросійських Установчих зборів $з$ даного питання, будь-якого опитування населення, самочинне проголошення Центральною Радою Української Республіки, із включенням до неї шляхом захоплення («захватным путем») тих або інших губерній та повітів, намагання вирішувати наперед («предрешить») суттєві реформи соціального ладу, відверте порушення ідеї цілісності держави і посягання на її честь через самостійні міжнародні переговори про мир. Таким чином, підсумував Н. Н. Познанський, оскільки сьогодні не можуть бути остаточно вирішеними питання про автономію України та її кордони, фракція вважає передчасним скликання Українських Установчих зборів ${ }^{18}$.

Далі слово мали представники єврейських громадських організацій М. Й. Футран та соціал-демократів-меншовиків оборонців А. А. Піддубний. На жаль, їх промови або проекти резолюцій в архівній справі відсутні.

Після них в обговорення включилися «важковаговики» харківського політикуму. Від соціал-демократів-об’єднаних (меншовиків) виступав В. І. Марков. У запропонованому ним проекті резолюції зазначалося, що «Харківська Міська Дума вважає («находит») найбільш доцільною та вигідною для демократії формою самовизначення України («Украйни») територіально-політичну автономію ії в етнографічних межах», пропонувалося визнати УЦР і Генеральний секретаріат як органи крайової влади на території, визначеної 3-м Універсалом, проведення плебісциту із гарантуванням прав національних меншин та підтримку виборів до Українських Установчих зборів. Водночас у проекті містилася пропозиція не розглядати Третій Універсал як конституційний акт, вважаючи, що остаточна конституція України має бути встановлена Українськими Установчими зборами ${ }^{19}$.

Позицію соціал-демократів - більшовиків захищала Е. В. Портигейс. Текст виголошеної нею резолюції повністю співпадав із ухвалою пленарного засідання Харківської 
Ради від 24 листопада 1917 р., де ця партія спромоглася отримати більшість. Він являв собою класичний приклад популістської риторики, притаманної цій партії. Представниця більшовиків акцентувала увагу на діях своєї партії у жовтні в Петрограді, пропонуючи зробити саме їх точкою відліку: «Беручи до уваги, що жовтнева робітнича і селянська революція скинула буржуазну диктатуру і забезпечила свободу самовизначення народів Російської республіки, що після жовтневої революції боротьба за самовизначення народів тісно пов'язана із підтримкою урядів рад в їх боротьбі із буржуазною контрреволюцією», - 3 таких рядків розпочинався пропонований думі проект рішення. Характерною рисою риторики більшовиків були критика «всієї практичної політики нинішніх вождів» УЦР; використання у множині поняття «урядів Рад»; жонглювання термінами «ради» та «Совєти»; звинувачення УЦР у «насильницькому без попереднього опитування населення» нав'язуванні влади населенню місцевостей, що не обирало Раду», ніби дії більшовиків у Петрограді не були насильницькими. Е. В. Портигейс запропонувала оголосити від імені Харківської Міської Думи, що «теперішня Центральна Рада не заслуговує на довіру трудових робітників і селянських мас», протестує проти анексії Харкова і Донецького басейна Радою, передачі частини Донецького басейну на поживу («на съедение») Каледіну, визнає владою в Харкові Раду робітничих і солдатських депутатів. Далі більшовики пропонували від імені Міської Думи підтримати «зі зброєю в руках трудівників шахт» в їх боротьбі $з$ Каледіним, залишити центром Донецького басейну Харків і визнати лише одну владу владу Совєтів. (Тут і далі вважаємо за доцільне використати термін «Совєти» без перекладу, щоби підкреслити специфіку термінології проекту резолюції більшовиків). У проекті їх резолюції пропонувалося вимагати негайного скликання з'їздів Всеукраїнського Совєта Робітничих і Солдатських Депутатів та Селянських Депутатів, які мають стати найвищою владою з правом обрати Центральний Виконавчий Комітет Совєтов - Раду - верховну владу в Українській Народній Республіці. На думку більшовиків, лише Рада, обрана з'їздом Совєтів робітничих і солдатських депутатів (симптоматично, що згадка про з'їзд Селянських депутатів в даному контексті відсутня - Д. Ч.), здатна забезпечити правильне скликання Українських Установчих зборів і забезпечити право всіх робітників і селян. Маємо зазначити, що за розмитими формулюваннями приховувався намір більшовиків забезпечити контрольований ними склад органів. Наостанок більшовики пропонували Думі єдиною законною верховною владою федеративної Російської республіки визнати Уряд Народних Комісарів ${ }^{20}$.

У негативному ставленні до Третього Універсалу позиції більшовиків збіглися із позицією фракції ПНС, яку виголосив А. В. Маклецов. На думку кадетів, неприйнятним підтримку Третього Універсалу робили такі чинники: оскільки єдиним і верховним органом, правомочним вирішувати долю Росії, мають бути загальноросійські Установчі збори, скликання Українських Установчих зборів як органу верховної влади означає («предполагает») повну незалежність України від Росії, що є неприпустимим; УЦР у нинішньому складі не оперта на загальне голосування і не може бути визнана органом, що відображає волю всього населення краю; Акт про включення Харківської губернії в територіальні межі України $є$ передчасним і не спирається на чітко висловлену волю всього населення губернії; УЦР зазіхає навіть на права Українських Установчих зборів; Третій Універсал як за джерелом свого походження, так і за змістом не може бути визнаний актом державного значення, таким, що має обов'язкову силу. В озвученій представником ПНС позиції значне місце посідало висловлення загальнотеоретичних підходів партії до вирішення національного питання. Підкреслювалося, зокрема, що ПНС завжди наполягала на необхідності децентралізації управління і законодавства в Росії, наданні прав автономії вищим територіальним самоврядним союзам в певних сферах місцевого господарського і національно-культурного життя, можливості об'єднання таких союзів у більші самоврядні області. Зокрема кадети наполягали, що партія висловлюється на користь широкої автономії України («Украйни») i за скликання Українського обласного Сейму за умов дотримання чотирьох принципів: питання це належить вирішенню загальноросійських Установчих зборів; єдність Росії не може бути порушеною; має бути забезпечено правильне висловлення волі населення; мають бути захищені («ограждены») права російської мови як загальнодержавної і міжнаціональної і дотримані інтереси національних меншин. Наостанок підкреслювалося, що партія твердо вірить у міцність братерських зв'язків великих народів єдиної вільної Росії ${ }^{21}$. 
Від соціалістів-революціонерів-оборонців Е. М. Ладнов подав проект резолюції фракції, який принципово не відрізнявся від пропозиції В. А. Ага-Бекова, але містив чітку формулу стосовно мотивів рішення Міської Думи: «... у час анархічного розвалу, який загрожує загибеллю Російській Державі, Центральна Українська Рада взяла на себе ініціативу організації обласної державної влади, яка намагається повернути країну на шлях відтворення державного порядку і посилення і збереження здобутків революції». Оборонці акцентували увагу на тому, що потрібно засудити виступи «безвідповідальних груп, які порушують постійно гарантії громадянських свобод» та визнати УЦР органом крайового державного управління «до часу ухвалення Загальноросійськими, Українськими та іншими Установчими Зборами остаточної форми Державного устрою і з'ясування меж окремих федеральних кордонів шляхом плебісциту» ${ }^{22}$.

Останнім в цей день виголосив заяву від польських громадських організацій гласний Я. М. Піотровський, підкресливши, що вітає український народ у його устремлінні до національного самовизначення, але, як представник нації, яка вже виділилася в автономну одиницю, він від участі в голосуванні з українського питання утримується ${ }^{23}$.

Оскільки робота Думи затягнулася до пізньої ночі, подальше обговорення було відкладено на наступне засідання. Воно розпочалося 2 грудня о 10.30 вечора в присутності 63 гласних. Дума спочатку вирішила два організаційних питання, обговорила проблеми зведення другої черги каналізації і потім повернулася до обговорення ставлення до Третього Універсалу ${ }^{24}$. Гласний Л. Б. Голубовський зачитав узгоджувальну резолюцію, яку підготувала фракція соціалістів-революціонерів і до якої приєдналися фракції українських соціал-демократів, українських соціалістів-революціонерів, українського демократичного блоку, соціалістів-революціонерів (оборонців), єврейської соціалістичної партії та єврейських громадських організацій ${ }^{25}$.

У відповідь гласний А. В. Маклєцов запропонував нову коротку резолюцію від імені фракції ПНС, в якій повторювалися принципові положення, виголошені 29 листопада. Представник фракції об'єднаних соціал-демократів (меншовиків) Б. П. Борушок-Павлов попросив відкласти обговорення питання через неприйнятність для фракції деяких пунктів узгодженої («согласительной») резолюції і бажання опрацювати такий текст резолюції, який збере якомога більшу кількість голосів для авторитетності вотуму Думи. Однак ця пропозиція була відхилена, і тому фракція меншовиків попросила поставити на голосування резолюцію, внесену фракцією на попередньому засіданні Думи ${ }^{26}$.

Після цього Дума перейшла до голосування тексту резолюції, яку можна взяти за основу. Почерговим голосуванням резолюції фракцій об'єднаних соціал-демократів (меншовиків), соціал-демократів (більшовиків) і ПНС були відхилені. Більшістю голосів за основу було прийнято узгоджувальну резолюцію, внесену фракцією соціалістів-революціонерів.

Наступною стадією роботи стало обговорення та ухвалення остаточної резолюції Думи. Від імені фракції народних соціалістів гласний Б. П. Куликов заявив, що, поділяючи принципи, викладені в першій частині узгоджувальної резолюції, фракція буде голосувати за цю частину і проти другої частини, деякі положення котрої фракція не поділяє, тому прохає голосувати резолюцію частинами і в разі ухвалення Думою другої частини буде голосувати проти резолюції в цілому. Е. В. Портигейс від імені фракції соціал-демократів (більшовиків) внесла до другої частини резолюції поправку про заміну слів: «Дума визнає крайовим органом владу генерального Секретаріату Української Центральної Ради» - словами «Дума визнає крайовим органом владу Всеукраїнської Обласної Ради робітничих, солдатських і селянських депутатів».

Голосуванням перша частина узгоджувальної резолюції була ухвалена більшістю в 41 голос з 63 присутніх. Проти поправки більшовиків проголосували 60 гласних, за - двоє. Друга частина резолюції була ухвалена більшістю в 37 голосів, а третя - 47 голосів. Після цього більшістю 36 голосів проти 17 при 6, що утрималися, була ухвалена узгоджена резолюція Харківської міської думи щодо ставлення до Третього Універсалу. Наводимо повний її текст:

«1) Харківська Міська Дума висловлюється за приєднання м. Харкова до Української демократичної республіки як складової частини Російської демократичної республіки на підставі ухвалених Центральною Радою положень про санкціонування Української республіки Загальноросійськими Установчими Зборами після висловлення волі всієї України на 
Українських Установчих Зборах, скликаних на основі 4-членної формули, із пропорційним представництвом, за умов гарантії прав національних меншин, причому остаточне 3'ясування волі народу має бути виявлено шляхом плебісциту, організованого Установчими Зборами. При цьому конструкція влади в Харківській губернії має бути такою, щоб сповна були гарантовані права національних меншин, що мешкають на Харківщині.

2) До часу створення Українськими Установчими Зборами правильно сконструйованої справжньо-народної влади, Міська Дума визнає крайовим органом владу генерального секретаріату Української Центральної Ради, яка спирається в справах управління Україною на органи революційної Української демократії, демократії національних меншин і органи місцевих самоврядувань.

3) Міська Дума вважає необхідним проведення виборів до Українських Установчих Зборів і здійснить всі заходи до того, щоби вибори відбулися за нормальних умов, що забезпечують вільне виявлення волі народів, які проживають в Україні» ${ }^{27}$.

Після голосування гласний А. В. Маклецов від імені фракції ПНС виголосив заяву, що обласний комітет партії ухвалив рішення брати участь у виборах до Українських Установчих зборів і буде виставляти самостійний партійний список. Після чого засідання закрилося о 1 год. 10 хвилин ночі.

Таким чином, на основі аналізу обговорення у Харківській Міській Думі Третього Універсалу УЦР можна виділити три типи партій, а отже й імовірно, харків'ян: підтримка головних положень (російські есери, українські та єврейські політичні партії та їх виборці), категоричне неприйняття (ТНСП - у перший день обговорення, ПНС, більшовики та ïx прихильники), невизначеність або бажання ухилитися від чіткої відповіді (меншовики, польські громадські організації, ТНСП у другий день обговорення та їх симпатики). Ухвалена Харківською Міською Думою резолюція відображала настрої близько третини політично активних городян та була співзвучною із настроями населення губернії, висловленими 7 грудня 1917 р. на п’ятому губернському селянському з'їзді ${ }^{28}$. Як свідчать документи, в Харкові більшою мірою підтримувалося позитивне ставлення до виборів в Українські Установчі Збори, дещо менше - входження до складу УНР, а найбільш контроверсійним залишалося ставлення до Генерального Секретаріату.

Той факт, що майже 40\% гласних не брали участі в засіданнях Думи при розгляді питання, свідчить, на наш погляд, про політичну інертність значної частини не лише політикуму, але і пересічних городян. Симптоматично, що не брали участі в засіданні Думи навіть абсолютна більшість гласних-більшовиків, сувора партійна дисципліна для яких була обов'язковим елементом поведінки. Представники фракцій есерівського напрямку сприймали Третій універсал як документ, що має відкрити шлях до переформатування не лише України, а й Російської Демократичної Республіки, а УЦР - як орган, що робить крок у правильному напрямку. Прихильники ТНСП та ПНС вважали, що Третій Універсал $є$ зазіханням на єдність Російської держави. Більшовики послідовно захищали інтереси перетворення країни за «совєтскім» зразком. Наостанок зауважимо, що наша реконструкція ставлення населення міста Харкова до знакових подій кінця 1917 р. є першою спробою в даному напрямку i, сподіваємося, може стимулювати подальші студії, зокрема, по інших містах України.

${ }^{1}$ Фарсобин В. В. О времени установлення Советской власти в Харькове // Исторические записки. 1963. № 73. С. 267-288; Історія міст і сіл Української РСР: Харківська область. Київ: УРЕ, 1967. С. 97-99; Тригуб П. М. Ліквідація міських дум і земств у період боротьби за встановлення і зміцнення Радянської влади на Україні (грудень 1917 - березень 1918 р.) // Питання історії народів СРСР. Х., 1972. Вип. 13. С. 26; Гамрецький Ю. М. До питання про час встановлення влади Рад у Харкові // Боротьба за владу Рад на Україні. Київ: Наукова думка, 1977. С. 99-119; та ін.

${ }^{2}$ Тинченко Я. Перша українсько-більшовицька війна (грудень 1917 - березень 1918 рр.). КиївЛьвів, 1996. С. 92-96; Студії з історії Української революції 1917-1921 років: на пошану Р. Я. Пирога: Зб. наук. пр. Київ, 2011; та ін.

${ }^{3}$ Бойко В. М. Участь українських партій в муніципальній кампанії 1917 р. // Український історичний журнал. 1997. № 5. С. 37; Добрунова Л. Е. Вибори до Харківської міської думи (липень 1917 року): підсумки, історичне значення // Вісник Харк. ун-ту. Сер.: Історія України. 1999. № 442. Вип. 3. С. 85-93. 
${ }^{4}$ Історія міста Харкова XX століття / О. Н. Ярмиш, С. I. Посохов, А. І. Епштейн та ін. Харків: Фоліо; Золоті сторінки, 2004. С. 155-163.

5 Доклад Центрального бюро по городским выборам // Известия Харьковской городской думы. 1917. № 4-5. С. 50-51.

${ }_{6}$ Ярмиш О. Н., Головко О. М. Харківське міське самоврядування на зламі століть: XIX-XX і XX-XXI. Досвід історії та сучасності. Харків: ХНУВС, 2004. С. 36-37.

7 Доклад Центрального бюро по городским выборам // Известия Харьковской городской думы. 1917. № 4-5. C. 50-51.

${ }^{8}$ Спирин Л. М. Россия, 1917 год: Из истории борьбы политических партий. М.: Мысль, 1987. C. $319-320$.

${ }^{9}$ История России. ХХ век. М., 1997, с. 173.

${ }^{10}$ Українська Центральна Рада: Документи і матеріали: у 2 т.: Т. 1. К., 1996. С. 398-401.

${ }^{11}$ Гамрецький Ю. М. Вказана праця. С. 105.

${ }^{12}$ Харьков и Харьковская губерния в Великой Октябрьской социалистической революции: Сб. док. и матер. Февраль 1917 - апр. 1918 гг. Х., 1957. С. 263-264.

13 Державний архів Харківської області (далі - ДАХО). Ф. 19. Оп. 1. Спр. 358. Арк. 244-248, 252-254зв. Частина резолюцій надрукована нами у хрестоматії: Історія Слобідської України : хрестоматія / Уклад. Д. М. Чорний. Х.: Видавець Олександр Савчук, 2016. С. 153-157.

${ }^{14}$ Голииин А. Д. Воспоминания. М.: Русский путь, 2008. С. 256.

${ }^{15}$ ДАХО. Ф. 19. Оп. 1. Спр. 358. Арк. 244, $2460 б$.

16 Там само. Арк. 246-2460б.

${ }^{17}$ Там само. Арк. 246.

${ }_{18}$ Там само. Арк. 246об-247.

19 Там само. Арк. 245об-246.

${ }^{20}$ Там само. Арк. 245-245об; Для порівняння: Харьков и Харьковская губерния в Великой Октябрьской социалистической революции: Сб. док. и матер. Февраль 1917 - апр. 1918 гг. Харьков: Обл. изд-во, 1957. С. 304-305.

${ }_{21}^{21}$ ДАХО. Ф. 19. Оп. 1. Спр. 358. Арк. 248.

22 Там само. Арк. 245.

${ }^{23}$ Там само. Арк. 244.

24 Там само. Арк. 252, 2520б., $2530 б$.

${ }^{25}$ Там само. Арк. 253 об.

${ }^{26}$ Там само. Арк. 254.

${ }^{27}$ Там само. Арк. 254-254об.

${ }^{28}$ Скальський В. В. Губернські селянські з'їзди як складові української революції 1917-1921рр. // Проблеми вивчення історії української революції 1917-1921 рр. Вип. 4. К., 2009. С. 95-96, 126. 